\title{
Physician job satisfaction related to actual and preferred job size
}

\author{
Lodewijk J. Schmit Jongbloed ${ }^{1,2}$, Janke Cohen-Schotanus ${ }^{2}$, Jan C. C. Borleffs ${ }^{2}$, Roy E. Stewart ${ }^{2}$ \\ and Johanna Schönrock-Adema ${ }^{2^{*}}$
}

\begin{abstract}
Background: Job satisfaction is essential for physicians' well-being and patient care. The work ethic of long days and hard work that has been advocated for decades is acknowledged as a threat for physicians' job satisfaction, well-being, and patient safety.

Our aim was to determine the actual and preferred job size of physicians and to investigate how these and the differences between them influence physicians' job satisfaction.
\end{abstract}

Method: Data were retrieved from a larger, longitudinal study among physicians starting medical training at Groningen University in 1982/83/92/93 ( $N=597)$. Data from 506 participants (85\%) were available for this study. We used regression analysis to investigate the influence of job size on physicians' job satisfaction (13 aspects) and ANOVA to examine differences in job satisfaction between physicians wishing to retain, reduce or increase job size.

Results: The majority of the respondents (57\%) had an actual job size less than 1.0 FTE. More than $80 \%$ of all respondents preferred not to work full-time in the future. Respondents' average actual and preferred job sizes were .85 FTE and .81 FTE, respectively. On average, respondents who wished to work less (35\% of respondents) preferred a job size reduction of 0.18 FTE and those who wished to work more (12\%) preferred an increase in job size of 0.16 FTE. Job size influenced satisfaction with balance work-private hours most $(\beta=-.351)$. Physicians who preferred larger job sizes were - compared to the other groups of physicians - least satisfied with professional accomplishments.

Conclusions: A considerable group of physicians reported a gap between actual and preferred job size. Realizing physicians' preferences as to job size will hardly affect total workforce, but may greatly benefit individual physicians as well as their patients and society. Therefore, it seems time for a shift in work ethic.

Keywords: Job satisfaction, Work ethics, Part time work, Balance work-private

\section{Background}

Physicians are very dedicated to their work due to a strong believe in the moral benefit and importance of care. This dedication results in long days and hard work. The importance of this work ethic has been passed on for generations and is already emphasized from the beginning of medical training. Consequently, undergraduate students, residents and physicians experience a high workload, which regularly results in reduced job satisfaction or even burnout or resigning from one's residency or medical profession [1-4].

\footnotetext{
*Correspondence: j.schonrock-adema@umcg.nl

2University Medical Center Groningen and University of Groningen, A.

Deusinglaan 1, 9713, AV Groningen, The Netherlands

Full list of author information is available at the end of the article
}

The burden of a heavy workload is widely acknowledged as a threat for patient safety [5-11]. In order to facilitate physicians to regulate their workload, the European Working Time Directive has been implemented in 1993 [12]. This Directive legally established that physicians do not work more than $48 \mathrm{~h}$ a week and no more than $8 \mathrm{~h}$ during shifts. Reduction of hours, however, seems difficult to implement in daily practice and physicians' workload remains high [13, 14]. A possible explanation for this problem is the still existing paradigm that the quality of doctors is dependent on their full-time availability to patients [15]. On a personal level, more and more physicians prefer to reduce their job size to achieve an acceptable workload [16-19]. The question arises, however, whether physicians actually 
effectuate their preferred job size and if not, how a difference between both relates to job satisfaction.

In general, job satisfaction of physicians is essential for optimal functioning and for quality of care. Higher job satisfaction not only tends to go along with increased well-being and better physical and mental health [20-25], but also with better patient outcomes and higher quality of care [11, 26-32]. A high workload may negatively affect job satisfaction and, hence, the quality of patient care. Therefore, it is important to investigate how job size, as a proxy for workload, is related to job satisfaction.

Our research questions were:

- What are the actual and preferred job sizes of physicians?

- How does actual job size influence physicians' job satisfaction?

- Are there differences in job satisfaction between physicians who prefer to retain, reduce or increase their job size?

\section{Methods}

\section{Participants and procedure}

The data for this study were retrieved from a larger, longitudinal study at the University of Groningen and University Medical Center Groningen. This longitudinal study encompassed four cohorts of physicians, who started medical training in $1982(n=166), 1983(n=167)$, $1992(n=171)$ and $1993(n=174)$. Since graduation, 81 out of the 678 physicians (12\%) dropped out of the study for several reasons, for instance not practicing medicine anymore, having emigrated, being chronically ill, or because they had deceased. Consequently, 597 graduates were left as potential participants in 2009-2010, of whom 506 (85\%) participated. In the current study, the respondents from the cohorts 1982 and 1983 were combined and named as the "older" cohorts $(n=265,52 \%$ males and $48 \%$ females, average age around 45 years) and those from the cohorts 1992 and 1993 were named as the "younger" cohorts $(n=241,49 \%$ males and $51 \%$ females, average age around 35 years).

Under the Dutch law, ethical review for this kind of study is not required. All participants were informed about the study and gave their consent to participate. Confidentiality was guaranteed and participation was voluntary.

Over a period of more than a decade, the respondents were interviewed telephonically several times. These interviews focused on various aspects of their work, among which their actual and preferred job size. Besides, at each moment of data collection a specific subject was inquired in-depth. In the last round of data collection $(2009 / 2010)$, the in-depth subject of inquiry focused on 'job satisfaction'. The current study focused on data collected in this last round, more specifically on actual and preferred job size and job satisfaction.

\section{Job size}

We asked physicians about their actual and their preferred job size in Full Time Equivalents (FTE). A fulltime job equals 1.0 FTE, which formally corresponds with 48 working hours a week. Part-timers were defined as those working less than 1.0 FTE [16]. Discrepancies between actual and preferred job size were also expressed in FTE. In our analysis, we differentiated between physicians who want to retain, reduce or increase their actual job size in the future.

\section{Job satisfaction}

Job satisfaction is described in sociological literature as a constellation of feelings about various aspects or facets of a job, which are context-specific [33, 34]. To operationalize physicians' job satisfaction as a multifaceted concept, we explored the medical sociological literature and included those aspects of physician job satisfaction that were most frequently mentioned in literature in our study. This resulted in the inclusion of 13 physician job satisfaction aspects. To warrant that these aspects cover the most important domains of the concept job satisfaction, we related them to the widely acknowledged taxonomy of Ostroff, which has been described as an appropriate conceptual framework for measuring job satisfaction [35-37] and which has been labelled as the most comprehensive classification of work environment perceptions [38] . This framework addresses three key domains of job satisfaction aspects: the cognitive, affective and instrumental domains. In the cognitive domain, we included (satisfaction with) opportunities for personal development $[39,40]$, professional accomplishments [17, 39, 41], control over work planning, control over work content $[17,42,43]$ and administrative work $[17,44]$. The affective domain was represented by (satisfaction with) appreciation from and cooperation with colleagues [17, 19], appreciation from and cooperation with support personnel [43-45] and the instrumental domain by (satisfaction with) cooperation with management $[17,19]$, balance between work and private hours [43, 44], appreciation from patients [17, 43, 44] and income [19, 44]. Each aspect of job satisfaction was rated on a 10 -point scale $(10=\mathrm{ex}$ tremely satisfied, $1=$ not satisfied at all).

\section{Data analysis}

In this study, actual and preferred job sizes were included as independent variables and the aspects of job satisfaction as dependent variables. Before deciding which statistical tests to use, we inspected the normality of the score distributions using a normal probability plot 
of the residuals. The significance level applied was $p \leq 0.05$. Since we found that data displayed approximate normal distributions, it was tenable to use parametric tests. We performed regression analysis to examine the influence of actual job size on the 13 aspects of job satisfaction with cohort and gender added as moderator variables. Unstandardized and standardized regression coefficients were presented with the $\mathrm{p}$ values. In addition, we conducted ANOVA to determine any differences in job satisfaction between physicians who wanted to retain, reduce or increase their job size. Statistical significant differences between actual and preferred job size were assessed by a $t$-test for the total group, the gender group and the cohorts group. The means and 95\% confidence intervals were calculated to assess the differences. We used the statistical package SPSS for Windows (version 23) [46] and SAS for Windows (version 9.4) [47].

\section{Results}

\section{Actual and preferred job size}

The group difference between physicians' average actual and preferred job size was 0.04 FTE (Table 1). Fortythree percent of the respondents had a full-time job, whereas $57 \%$ worked part-time (Table 2). Physicians who wanted to work less $(35 \%)$ preferred an average reduction of 0.18 FTE $($ CI95\% $=0.17-0.19)$, those who wanted to work more $(12 \%)$ preferred an average increase of 0.16 FTE $($ CI95\% $=0.14-0.18)$. Mean difference between full-time and part-time for actual job size was 0.26 FTE (CI95\%: 0.24-0.28; $p<0.001$ ). Mean difference between full-time and part-time for preferred job size was 0.13 FTE (CI95\% : 0.11-0.15; $p<0.001)$.

With respect to both actual and preferred job size, significant differences were found for gender and cohort. Male physicians worked and preferred to work more than females did $(F=152.07, p<0.01$ and $F=116.96, p<0.01$ respectively) (Table 1), and the actual and preferred job sizes of the younger physicians (cohorts 1992 and 1993) were larger than those of physicians from the older cohorts (1982 and 1983) ( $F=4.51, p \leq 0.05$ and $F=6.60$, $p \leq 0.05$ respectively). We found an interaction effect for gender and cohort. Younger females work more and prefer to work more than their older colleagues $(F=11.41$, $p<0.01$ and $F=18.64, p<0.01$ ).

\section{The influence of actual job size, cohort and gender on job} satisfaction

We found that 'actual job size' influenced physicians' satisfaction with balance work - private hours and control over work planning negatively $(\beta=-0.351$, and $\beta=-0.151$, respectively) (Table 3 ) and that it influenced their satisfaction with professional accomplishments positively $(\beta=0.126)$. Physicians from the older cohorts were more satisfied with control over work planning $(\beta=0.136)$, control over work content $(\beta=0.094)$ and balance work-private hours $(\beta=0.082)$ than their colleagues from the younger cohorts. In addition, physicians from the older cohorts were less satisfied with opportunities for personal development $(\beta=-0.157)$. Female physicians were less satisfied with professional accomplishments $(\beta=-0.113)$, control over work planning $(\beta=-0.135)$, cooperation with support personnel $(\beta=-0.114)$ and balance work-private hours $(\beta=-0.135)$ than their male colleagues were.

\section{Differences between actual and preferred job size and the impact on job satisfaction}

For three aspects of job satisfaction, we found significant differences between physicians who wanted to retain, reduce or increase their job size (Table 4). In comparison with the other groups of physicians, full-time working physicians who wished to reduce their job size were

Table 1 Average actual and preferred job size (in Full-Time Equivalents (FTE)) and their difference for male and female physicians of the cohorts $82 / 83$ and $92 / 93$

\begin{tabular}{|c|c|c|c|c|c|c|}
\hline \multirow{2}{*}{$\begin{array}{l}\text { Gender/ } \\
\text { Cohort }\end{array}$} & \multirow[t]{2}{*}{$N$} & \multicolumn{2}{|c|}{ Actual job size ${ }^{a}$} & \multicolumn{2}{|c|}{ Preferred job size } & \multirow{2}{*}{$\begin{array}{l}\text { Difference between } \\
\text { actual and preferred } \\
\text { job size (FTE) }\end{array}$} \\
\hline & & Mean & $95 \%$ C.I. $^{b}$ & Mean & $95 \%$ C.I. $^{b}$ & \\
\hline Total & 506 & 0.85 & $0.84-0.87$ & 0.81 & $0.80-0.82$ & 0.04 \\
\hline Males & 256 & 0.93 & $0.92-0.94$ & 0.87 & $0.85-0.98$ & 0.06 \\
\hline Females & 250 & 0.77 & $0.75-0.79$ & 0.75 & $0.73-0.77$ & 0.02 \\
\hline Cohorts 82/83 & 265 & 0.84 & $0.82-0.86$ & 0.80 & $0.78-0.82$ & 0.04 \\
\hline Males & 137 & 0.94 & $0.92-0.96$ & 0.87 & $0.85-0.90$ & 0.07 \\
\hline Females & 128 & 0.74 & $0.71-0.77$ & 0.72 & $0.70-0.74$ & 0.02 \\
\hline Cohorts 92/93 & 241 & 0.86 & $0.85-0.88$ & 0.82 & $0.81-0.84$ & 0.04 \\
\hline Males & 119 & 0.92 & $0.90-0.94$ & 0.86 & $0.84-0.87$ & 0.06 \\
\hline Females & 122 & 0.81 & $0.78-0.84$ & 0.79 & $0.77-0.81$ & 0.02 \\
\hline
\end{tabular}

${ }^{\mathrm{a}} 1 \mathrm{FTE}=$ full time job ${ }^{\mathrm{b}} \mathrm{C} . \mathrm{I} .=$ confidence interval 
Table 2 Numbers of full-time (FT) and part-time (PT) working physicians who wish to retain, reduce or increase their actual job size for cohort and gender

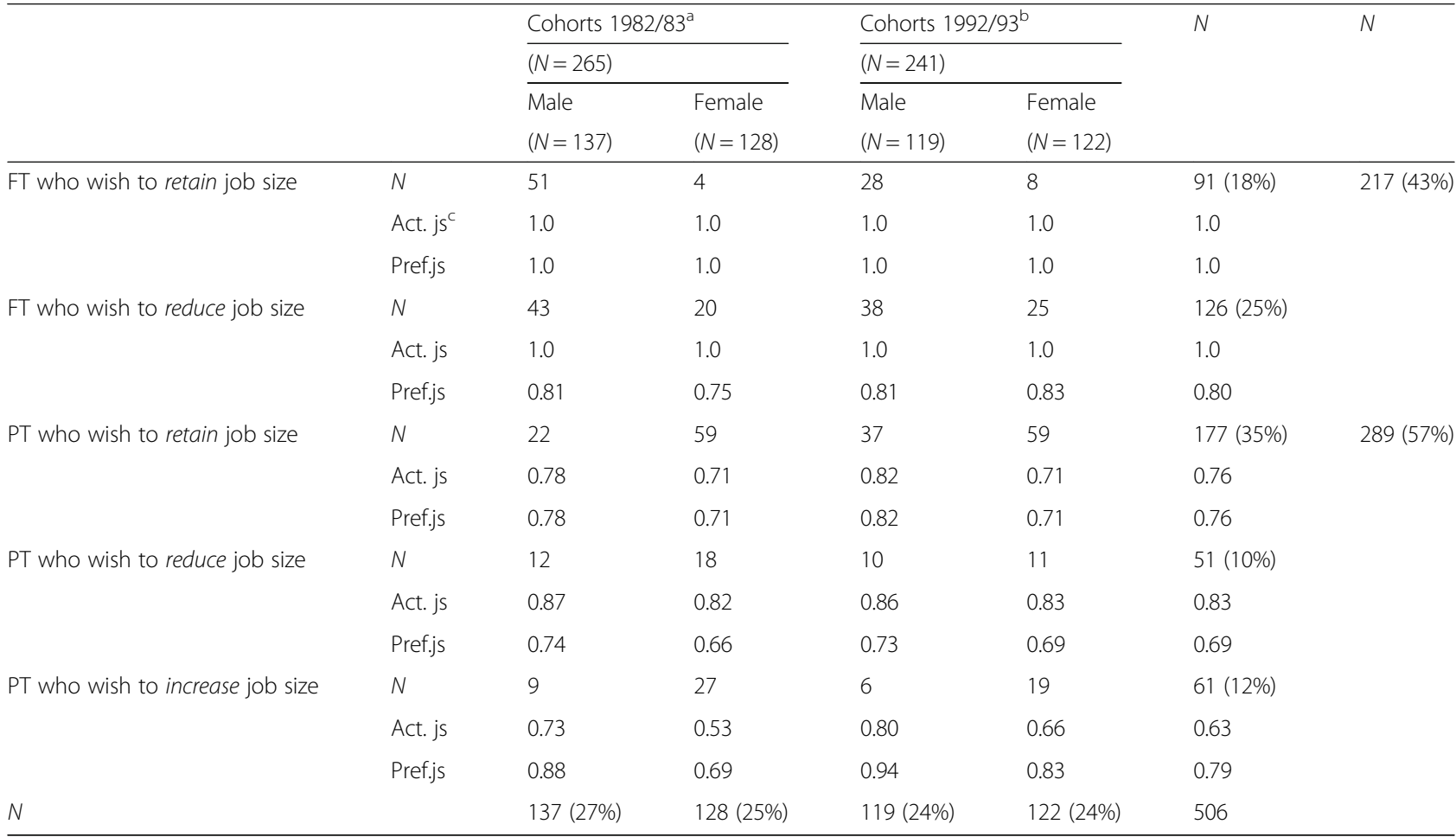

${ }^{\mathrm{a}} 20$ years in practice, ${ }^{\mathrm{b}} 10$ years in practice, ${ }^{\mathrm{c}}$ actual and preferred job size in FTE (mean scores)

least satisfied with their balance work-private hours $(F=14.71 ; p<0.01)$. Similarly, part-timers who wished to reduce their job size were least satisfied with cooperation with management $(F=3.18 ; p \leq 0.05)$, and part-timers who wished to increase their job size were least satisfied with their professional accomplishments $(F=2.33 ; p \leq 0.05)$.

\section{Discussion}

The objective of this study was to gain insight into the actual and preferred job sizes of physicians in relation to job satisfaction. We found that physicians had on average a larger job size than they preferred. Job size relates negatively to job satisfaction, especially to the aspect balance work-private hours. Based on the preferred job sizes, a job size of 4 days seems to be ideal for most physicians.

The overall difference between the actual and preferred job sizes of the respondents was small: 0.04 FTE. This outcome may suggest that there is not a real problem. However, some physicians are satisfied with their actual job size (about half), some prefer to work less (about a third) whilst the rest prefers to work more. This means that, on an individual level, the difference between actual and preferred job size may actually be substantial and thus problematic. On average, those who preferred to work less or more wished to reduce and increase their job sizes, on average, with around a day respectively. So, on balance, the difference between actual an preferred job size is rather small which implies that allowing physicians to realize their preferences may not have a major effect on the total workforce. However, attuning actual job sizes to physicians' preferences may be of vital importance to individual physicians. A better fit between actual and preferred job size may benefit job satisfaction, which - in turn - seems to be in the interest of the health care setting as a whole. High job satisfaction may benefit society through increased well-being and physical and mental health [20-25] and decreased burnout, intention to leave and job or career turnover [32, 48]. Moreover, higher job satisfaction may benefit society through better quality of care, patient outcomes and patient satisfaction [11, 26-32]. Considering the fact that four out of five physicians worked part-time or preferred to work part-time, we conclude that - at least in the Netherlands - the old stereotype of 'the 24/7 working physician' [17] does not fit anymore. For the current population of physicians, part-time work seems the solution to reduce the heavy workload and to find a balance between professional and personal life.

Gender differences were found between actual and preferred job sizes with males having larger job sizes. A possible explanation for this outcome may be that from the historical perspective it has been accepted for many 
Table 3 Results of the multiple linear regression analysis to analyse the influence of actual job size, cohort and gender on aspects of job satisfaction

\begin{tabular}{|c|c|c|c|c|c|c|}
\hline \multirow[t]{2}{*}{ Domain } & \multicolumn{3}{|l|}{ Dependent variables } & \multirow{2}{*}{$\begin{array}{l}\text { Independent variable } \\
\text { Job size }{ }^{a}\end{array}$} & \multicolumn{2}{|c|}{ Moderator variables } \\
\hline & Aspects of job satisfaction & & Constant & & Cohort $^{b}$ & Gender $^{c}$ \\
\hline \multirow[t]{15}{*}{ Cognitive domain } & Opportunities for personal development & P & $<0.001$ & 0.674 & 0.001 & 0.949 \\
\hline & & B & 7.509 & 0.001 & -0.327 & -0.007 \\
\hline & & $\beta$ & & 0.021 & -0.157 & -0.003 \\
\hline & Satisfaction with professional accomplishments & $\mathrm{p}$ & $<0.001$ & 0.010 & 0.840 & 0.022 \\
\hline & & B & 7.351 & 0.006 & -0.015 & -0.189 \\
\hline & & $\beta$ & & 0.126 & -0.009 & -0.113 \\
\hline & Control over work planning & $\mathrm{p}$ & $<0.001$ & 0.002 & 0.002 & 0.006 \\
\hline & & B & 7.872 & -0.013 & 0.387 & -0.386 \\
\hline & & $\beta$ & & -0.151 & 0.136 & -0.135 \\
\hline & Control over work content & $\mathrm{p}$ & $<0.001$ & 0.321 & 0.033 & 0.122 \\
\hline & & B & 7.284 & -0.004 & 0.225 & -0.184 \\
\hline & & $\beta$ & & -0.049 & 0.094 & -0.077 \\
\hline & Administrative work & $\mathrm{p}$ & $<0.001$ & 0.136 & 0.743 & 0.632 \\
\hline & & B & 5.977 & -0.007 & 0.044 & 0.073 \\
\hline & & $\beta$ & & -0.076 & 0.015 & 0.024 \\
\hline \multirow[t]{12}{*}{ Affective domain } & Appreciation from colleagues & $p$ & $<0.001$ & 0.842 & 0.398 & 0.152 \\
\hline & & B & 7.896 & -0.001 & -0.058 & -0.112 \\
\hline & & $\beta$ & & -0.010 & -0.037 & -0.072 \\
\hline & Appreciation from support personnel & $\mathrm{p}$ & $<0.001$ & 0.437 & 0.217 & 0.263 \\
\hline & & B & 7.494 & 0.002 & 0.084 & -0.086 \\
\hline & & $\beta$ & & 0.040 & 0.056 & -0.057 \\
\hline & Cooperation with colleagues & $p$ & $<0.001$ & 0.865 & 0.198 & 0.285 \\
\hline & & B & 7.713 & 0.001 & -0.103 & -0.097 \\
\hline & & $\beta$ & & 0.009 & -0.057 & -0.054 \\
\hline & Cooperation with support personnel & $\mathrm{p}$ & $<0.001$ & 0.875 & 0.831 & 0.025 \\
\hline & & B & 7.508 & -0.000 & 0.015 & -0.173 \\
\hline & & $\beta$ & & -0.008 & 0.010 & -0.114 \\
\hline \multirow[t]{12}{*}{ Instrumental domain } & Cooperation with management & $\mathrm{p}$ & $<0.001$ & 0.173 & 0.585 & 0.208 \\
\hline & & B & 7.066 & -0.006 & -0.073 & -0.192 \\
\hline & & $\beta$ & & -0.082 & -0.029 & -0.076 \\
\hline & Balance work-private hours & $\mathrm{p}$ & $<0.001$ & $<0.001$ & 0.050 & 0.004 \\
\hline & & B & 9.388 & -0.028 & 0.211 & -0.349 \\
\hline & & $\beta$ & & -0.351 & 0.082 & -0.135 \\
\hline & Appreciation from patients & $p$ & $<0.001$ & 0.519 & 0.149 & 0.654 \\
\hline & & B & 7.770 & -0.001 & 0.091 & -0.032 \\
\hline & & $\beta$ & & -0.033 & 0.065 & -0.023 \\
\hline & Income & $p$ & $<0.001$ & 0.678 & 0.145 & 0.738 \\
\hline & & B & 7.426 & 0.002 & 0.153 & 0.039 \\
\hline & & $\beta$ & & 0.021 & 0.066 & 0.017 \\
\hline
\end{tabular}

${ }^{\mathrm{a}} 1 \mathrm{FTE}=$ full time job

${ }^{\mathrm{b} C o h o r t s} 1982$ and 1983 versus cohorts 1992 and 1993 (reference group)

'Males (reference group) versus females

$p=p$ value; $\mathrm{B}=$ unstandardized regression coefficient; $\beta=$ standardized regression coefficient

The bold values represent statistical significance $(p \leq 0.05)$ 
Table 4 Average scores on job satisfaction aspects and differences between Full-Time (FT) and Part-Time (PT) working physicians who want to reduce, retain or increase their job size

\begin{tabular}{|c|c|c|c|c|c|c|c|}
\hline \multirow[t]{3}{*}{ Job satisfaction aspects } & \multicolumn{2}{|c|}{ Retain job size $^{a}$} & \multicolumn{2}{|c|}{ Reduce job size } & \multirow{3}{*}{$\begin{array}{l}\text { Increase job size } \\
\text { PT }(N=61) \\
\text { Mean (SD) }\end{array}$} & \multirow[t]{3}{*}{$F^{b}$} & \multirow[t]{3}{*}{$p^{*}$} \\
\hline & $\mathrm{FT}(N=91)$ & PT $(N=177)$ & $\mathrm{FT}(N=126)$ & $\mathrm{PT}(N=51)$ & & & \\
\hline & Mean $(S D)^{b}$ & Mean (SD) & Mean (SD) & Mean (SD) & & & \\
\hline Opportunities for personnel development & $7.50(1.10)$ & $7.40(0.93)$ & $7.45(1.21)$ & $7.32(0.90)$ & $7.56(1.26)$ & 0.50 & 0.73 \\
\hline Own professional accomplishments & $7.90(0.77)$ & $7.80(0.72)$ & $7.90(0.85)$ & $7.72(0.70)$ & $7.54(1.22)$ & 2.33 & 0.05 \\
\hline Control over work planning & $6.90(1.46)$ & $6.93(1.41)$ & $6.51(1.45)$ & $6.57(1.17)$ & $6.70(1.52)$ & 2.01 & 0.09 \\
\hline Control over work content & $7.19(1.34)$ & $6.99(1.13)$ & $6.87(1.22)$ & $6.90(1.15)$ & $7.09(1.25)$ & 1.10 & 0.36 \\
\hline Administrative work & $5.34(1.60)$ & $5.57(1.51)$ & $5.27(1.46)$ & $5.23(1.41)$ & $5.61(1.48)$ & 1.20 & 0.31 \\
\hline Appreciation from colleagues & $7.87(0.69)$ & $7.80(0.72)$ & $7.73(0.73)$ & $7.79(0.66)$ & $7.62(1.14)$ & 1.01 & 0.34 \\
\hline Appreciation from support personnel & $7.68(0.89)$ & $7.69(0.66)$ & $7.64(0.83)$ & $7.56(0.61)$ & $7.68(1.04)$ & 0.32 & 0.87 \\
\hline Cooperation with colleagues & $7.60(0.95)$ & $7.67(0.89)$ & $7.68(0.94)$ & $7.65(0.65$ & $7.63(1.04)$ & 0.15 & 0.96 \\
\hline Cooperation with support personnel & $7.47(0.92)$ & $7.38(0.67)$ & $7.39(0.69)$ & $7.24(0.69)$ & $7.43(0.96)$ & 0.72 & 0.58 \\
\hline Cooperation with management & $6.53(1.39)$ & $6.46(1.03)$ & $6.22(1.31)$ & $5.68(1.63)$ & $6.71(1.27)$ & 3.18 & 0.01 \\
\hline Balance work-private hours & $7.05(1.29)$ & $7.25(1.16)$ & $6.40(1.31)$ & $6.58(1.12)$ & $7.59(1.13)$ & 14.71 & $<0.01$ \\
\hline Appreciation from patients & $7.63(0.76)$ & $7.68(0.63)$ & $7.69(0.75)$ & $7.61(0.61)$ & $7.80(0.70)$ & 0.69 & 0.60 \\
\hline Income & 7.69 (1.26) & $7.70(0.99)$ & 7.63 (1.35) & $7.47(1.06)$ & $7.56(1.14)$ & 0.47 & 0.76 \\
\hline
\end{tabular}

${ }^{\mathrm{a}} 1 \mathrm{FTE}=$ full time job ${ }^{\mathrm{b}}$ Degrees of freedom $=4$

* Bold values represent statistical significance $(p \leq 0.05)$

years that females have different family commitments than males. In the Netherlands, for example, females predominantly take the responsibility for raising children. Consequently, female physicians may feel a stronger need for working part-time. Our data show indeed that females worked more often part-time than their male colleagues did. However, we also found that around $40 \%$ of the full-time working males preferred to reduce their job sizes. A possible reason for this finding may be the changes in (European) society in which males take more and more responsibilities in family commitments. Our data indicate, however, that realizing the preferred job size is more difficult for males than females. It seems very well possible that in a predominantly masculine work context - mainly male specialists and health care employers - managers are less inclined to permit male physicians to work part-time. An often-heard argument against working part-time in the medical field is that it will lead to a higher frequency of handovers, which may hinder continuity of care $[5,49,50]$. We wonder, however, how valid this argument is: We noticed that this argument is seldom used when a physician decides to spend more time on research or teaching which, consequently, also leads to less time for patient care. Since having the preferred job size is beneficial for physicians' well-being [17, 49] and for quality of care [5, 51], we advise health care managers to appreciate the realization of physicians' preferred job sizes.

The differences between males and females with respect to actual and preferred job sizes were smaller in the younger cohorts than in the older cohorts. These differences are mainly attributable to the female physicians: female physicians from younger cohorts had relatively larger job sizes and preferred larger job sizes than their female colleagues from the older cohorts did. This outcome is a clear reflection of a societal shift that has taken place in many western countries over the past years: nowadays, it is much more accepted that females have substantial job sizes and that males take up more family commitments.

Our second aim was to examine how actual job size influences physicians' job satisfaction. Among the job satisfaction aspects that were significantly influenced, the effect of job size on the balance work-private hours probably is the most relevant one. The smaller the job size, the more satisfied physicians were with this balance. Our empirical outcomes substantiate earlier notions that a good balance between professional and family life might be an important determinant of job satisfaction $[41,49,52,53]$.

The fact that the mismatch between actual and preferred job size was larger for male than for female physicians may explain why full-time working male physicians who preferred to reduce their job sizes were least satisfied with the balance between work-private hours. The need for a better balance between work and their private life seems to be an important reason for preferring a part-time job.

Lower satisfaction with cooperation with management seems to be a motive for desiring a further reduction of job size. It may be that the cooperation between physicians and management not only influences physicians' job satisfaction, but also physicians' preferences 
regarding job size. Low satisfaction with professional accomplishments seems to be a motive for desiring an increase in job size. Probably, it is difficult to achieve career goals in a too limited job size. We noted that mainly part-time working female physicians wish to increase their job size.

The results of our study suggest that the optimal job size is 4 days a week. Working 4 days a week seems to be sufficient to find a better balance between work and private life, but also to create enough possibilities for professional development. However, further research is needed to explore what the optimal job size is to satisfy these aspects of job satisfaction and which factors influence the optimal balance between job size and these aspects of job satisfaction. We find it important to include gender in these studies, because, roughly speaking, females wish to increase their job sizes, whereas their male colleagues prefer to reduce their job sizes. Other factors that may be relevant for physicians' preferred or optimal job size are marital status, numbers of children, and other socioeconomic factors.

This study has several strengths. First, we considered job size as a continuous variable. Most studies dichotomized their research population in part-time and fulltime working physicians $[17,38,49,54]$. Because of our approach, we were able to get more detailed information about the exact size of the preferred reduction or increase in job size. Second, we also differentiated between physicians who wished to retain, increase or decrease their job size. This breakdown added to the average outcomes, as it clearly demonstrated substantial mismatches between actual and preferred job sizes of physicians who wanted to change their job sizes.

Third, almost four complete cohorts of graduates were included in our study, which means that the risk of response bias in the outcomes is reduced.

A first limitation of our study is that all graduates studied at the same medical school, which might limit the generalizability of our outcomes. However, our study population is representative of the Dutch population of physicians as the curricula at the Dutch medical schools are very similar and all schools use the Dutch National Blueprint for medical education [55]. Furthermore, more than half of our graduates enrolled in specialty programs of other universities and practice in other parts of the country. The question arises however, how well our outcomes generalize to other countries. It is possible that our results are mainly applicable to the Europe, since the European countries fall under the same legislation. A second limitation is that we restricted our measurement of job satisfaction to the 13 aspects that, in literature, seemed to be most relevant to physicians. It is possible that there are other aspects of job satisfaction that are important to physicians. However, since we were able to address the three domains of Ostroff's taxonomy - a classification that has been lauded as an all-inclusive, solid integration of the literature [38] - with these 13 aspects we feel confident that we covered the concept job satisfaction of physicians broadly. A third limitation is that job satisfaction also might be influenced by social factors like the marital status, number of children or other socioeconomic factors. However, these confounder variables were not available in the longitudinal dataset from which we retrieved the data for this study. Therefore, further research is necessary to examine the influences of such confounding variables. A fourth limitation is that our data are based on self-assessments. Nevertheless, job satisfaction can only be measured by asking people how satisfied they feel. Finally, our study is restricted to physicians in their begin and middle career stages which might limit the generalizability of our findings to other groups. However, there are indications that our conclusions are also valid for residents and medical students in their practice years: there is evidence that also in these groups a preference for part-time work exists as $15 \%$ of male residents and $30 \%$ of female residents work part-time [56]. Furthermore, burnout is highly prevalent among residents $(27-75 \%)$ and medical students $(28 \%-45 \%)$ [3, 14], which may also be a sign of too heavy workloads. Future research should investigate whether there also exist differences between the actual and preferred job sizes of medical students and residents and, if so, how these differences influence their job satisfaction.

\section{Conclusion}

Despite the work ethic of long days and hard work that has been advocated for decades, this study shows that the large majority of today's physicians prefer to work part-time. It seems that it is time for a shift in work ethic, considering the beneficial effects of working part-time as reported in literature on physician health and patient care, and the fact that actualizing all preferred job sizes would hardly affect the total workforce. It may be more ethical towards physicians themselves, their patients, and society as a whole to allow physicians to realize their preferred job size as they know their personal boundaries and needs best. On average, physicians preferred to work 4 days a week. Job size mainly influenced satisfaction with the balance between work and private hours. We plea for more acceptance of working part-time, because a better match between actual and preferred job size is important for physicians' job satisfaction and, thus, on the quality of care. 


\section{Funding}

Not applicable.

\section{Availability of data and materials}

The data for this study were retrieved from a larger, longitudinal study at the University of Groningen and University Medical Center Groningen. Datasets generated and/or analyzed during the current study are kept at the Center for Education Development and Research in Health Professions (CEDAR), University of Groningen and University Medical Center Groningen, the Netherlands. Any questions or requests regarding the data can be addressed to Johanna Schönrock-Adema (j.schonrock-adema@umcg.nl).

\section{Authors' contributions}

JCS initiated the study and LSJ and JCS were responsible for collecting the data for this study. JCS and LSJ conceived the article. RS, LSJ, JSA and JCS were responsible for the data analysis. All authors contributed to the interpretation of the data. LSJ, JCS and JSA were mainly responsible for writing the draft. JB and RS provided input and contributed to several versions of the draft. All authors read and approved the final version of the manuscript.

\section{Competing interests}

The authors declare that they have no competing interests.

\section{Consent for publication}

Not applicable.

\section{Ethics approval and consent to participate}

The legal framework for ethics approval requirements for scientific research in the Netherlands is provided by the Medical Research Involving Human Subjects Act (in Dutch: WMO). Article 1b of the WMO stipulates that ethics approval of a research project is legally required if a) the research qualifies as medical research or b) if participants are subjected to certain behavioral requirements. Neither one of these two requirements apply to the current research project (www.ccmo.nl).

Verbal consent was obtained from each participant. Before the questionnaire was administered, potential participants were asked the question: "In the year 2000 you have participated in a longitudinal study on physician job satisfaction. We are currently conducting a follow-up study. Would you consent to participating again by answering questions about your professional situation and your job satisfaction? The answers you provide will be treated confidentially." Of the 299 potential participants, 292 consented to participate. 7 potential participants withheld consent or indicated they had no time to participate.

\section{Publisher's Note}

Springer Nature remains neutral with regard to jurisdictional claims in published maps and institutional affiliations.

\section{Author details}

${ }^{1}$ Schmit Jongbloed Advies, Hofbrouckerlaan 30, 2341 LP Oegstgeest, The Netherlands. 'University Medical Center Groningen and University of Groningen, A. Deusinglaan 1, 9713, AV Groningen, The Netherlands.

Received: 15 September 2016 Accepted: 20 April 2017

Published online: 11 May 2017

\section{References}

1. Barnett RC, Gareis KC, Carr PL. Career satisfaction and retention of a sample of women physicians who work reduced hours. J Women's Heal. 2005;14:146-54.

2. Dyrbye LN, Freischlag J, Kaups KL, Oreskovich MR, Satele DV, Hanks JB, et al. Work-home conflicts have a substantial impact on career decisions that affect the adequacy of the surgical workforce. Arch Surg. 2012;147:933-9.

3. Prins JT, Hoekstra-Weebers JEHM, van de Wiel HBM, Gazendam-Donofrio SM, Sprangers F, Jaspers FC, et al. Burnout among Dutch medical residents. Int J Behav Med. 2007;14:119-25.

4. Willcock SM, Daly MG, Tennant CC, Allard BJ. Burnout and psychiatric morbidity in new medical graduates. Med J Aust. 2004;181:357-60. Available from: https://www.mja.com.au/journal/2004/181/7/burnout-and-psychiatricmorbidity-new-medical-graduates.
5. Maybury C. The European working time directive: a decade on European legislation to curb junior doctors' working hours is still a contentious issue 10 years on as debates about patient safety, training, and work-life balance continue. Lancet. 2014;384:1562-3. Elsevier Ltd. Available from: http://dx.doi. org/10.1016/S0140-6736(14)61972-3.

6. Barger LK, Ayas NT, Cade BE, Cronin JW, Rosner B, Speizer FE, et al. Impact of extended-duration shifts on medical errors, adverse events, and attentional failures. Plos Med. 2006;3:e487.

7. Desai SV, Feldman L, Brow L, Dezube R, Yeh H-C, Punjabi N, et al. Effect of the 2011 vs 2003 duty hour regulation - compliant models on sleep duration, trainee education, and continuity of patient care among internal medicine house staff. J Am Med Assoc. 2013;173:649-55

8. Halbesleben JRB, Rathert C. Linking physician burnout and patient outcomes: exploring physicians and patients. Health Care Manage Rev. 2008;33:28-39.

9. Shanafelt TD, Bradley KA, Wipf JE, Back AL. Burnout and self-reported patient care in an internal medicine residency program. Ann Intern Med. 2002;136: 358-67. Available from: http://www.ncbi.nlm.nih.gov/pubmed/19730177.

10. Taylor C, Graham J, Potts H, Candy J, Richards M, Ramirez A. Impact of hospital consultants' poor mental health on patient care. Br J Psychiatry. 2007:190:268-9.

11. Williams ES, Manwell LB, Konrad TR, Linzer M. The relationship of organizational culture, stress, satisfaction, and burnout with physicianreported error and suboptimal patient care: results from the MEMO study. Health Care Manage Rev. 2007;32:203-12.

12. Smet M. Council Directive 93/104/EC of 23 November 1993 concerning certain aspects of the organization of working time. Off J Eur Union. 1993; L307:0018-24. Available from: http://eur-lex.europa.eu/legal-content/EN/TXT/ ?uri=CELEX:31993L0104.

13. Goetz K, Musselmann B, Szecsenyi J, Joos S. The influence of workload and health behavior on job satisfaction of general practitioners. Fam Med. 2013:45:95-101. Available from: http://www.stfm.org/ FamilyMedicine/Vol45Issue2/Goetz95.

14. Ishak WW, Lederer S, Mandili C, Nikravesh R, Seligman L, Vasa M, et al. Burnout during residency training: a literature review. J Grad Med Educ. 2009;1:236-42.

15. Richards T. The European working time directive. Running out of time. $\mathrm{Br}$ Med J. 2009;338:914-7.

16. Heiligers PJM, Hingstman L. Career preferences and the work-family balance in medicine: gender differences among medical specialists. Soc Sci Med. 2000;50:1235-46.

17. McMurray JE, Heiligers PJM, Shugerman RP, Douglas JA, Gangnon RE, Voss C, et al. Part-time medical practice: where is it headed? Am J Med. 2005;118: 87-92. Available from: http://www.ncbi.nlm.nih.gov/pubmed/15639215.

18. Norman R, Hall J. Can hospital-based doctors change their working hours? Evidence from Australia. Intern Med J. 2014;44:658-64.

19. Scheurer D, McKean S, Miller J, Wetterneck T. U.S. physician satisfaction: a systematic review. J Hosp Med. 2009;4:560-8.

20. Faragher AEB, Cass M, Cooper CL, Faragher EB, Cass M, Cooper CL, et al. The relationship between job satisfaction and health: a meta analysis. Occup Environ Med. 2005:62:105-12.

21. Grunfeld E, Whelan TJ, Zitzelsberger L, Willan AR, Montesanto B, Evans WK. Cancer care workers in Ontario: prevalence of burnout, job stress and job satisfaction. Can Med Assoc J. 2000;163:166-9.

22. Linzer M, Baier Manwell L, Mundt M, Williams E, Maguire A, McMurray J, et al. Organizational climate, stress, and error in primary care: the MEMO study. In: Henriksen K, Battles JB, Marks ES, Lewin Dl, editors. Adv. patient Saf. From Res. to implementation. Rockville: AHRQ Publication; 2005. p. 65-77.

23. Wallace JE, Lemaire JB, Ghali WA. Physician wellness: a missing quality indicator. Lancet. 2009;374:1714-21. Elsevier Ltd. Available from: http://dx. doi.org/10.1016/S0140-6736(09)61424-0.

24. Weng H-C, Hung C-M, Liu Y-T, Cheng Y-J, Yen C-Y, Chang C-C, et al. Associations between emotional intelligence and doctor burnout, job satisfaction and patient satisfaction. Med Educ. 2011:45:835-42.

25. Williams ES, Konrad TR, Scheckler WE, McMurray JE, Gerrity M, Schwartz M. Understanding physicians' intentions to withdraw from practice: the role of job satisfaction, job stress, mental and physical health. Health Care Manage Rev. 2010:35:105-15.

26. Grembowski D, Paschane D, Diehr P, Katon W, Martin D, Patrick DL. Managed care, physician job satisfaction, and the quality of primary care. J Gen Intern Med. 2005;20:271-7. 
27. Haas JS, Cook EF, Puopolo AL, Burstin HR, Cleary PD, Brennan TA. Is the professional satisfaction of general internists associated with patient satisfaction? J Gen Intern Med. 2000;15:122-8.

28. Hinami K, Whelan CT, Miller JA, Wolosin RJ, Wetterneck TB. Person-job fit: an exploratory cross-sectional analysis of hospitalists. J Hosp Med. 2013;8:96-101.

29. Scheepers RA, Boerebach BCM, Arah OA, Heineman MJ, Lombarts KMJMH. A systematic review of the impact of physicians' occupational well-being on the quality of patient care. Int J Behav Med. 2015;22:683-99.

30. Shanafelt TD, Boone S, Tan L, Dyrbye LN, Sotile W, Satele D, et al. Burnout and satisfaction with work-life balance among US physicians relative to the general US population. Arch Intern Med [Internet]. 2012;172:1377-85. Available from: http://www.ncbi.nlm.nih.gov/pubmed/22911330, http:// archinte.jamanetwork.com/data/Journals/INTEMED/25300/ioi120042_1377_ 1385.pdf.

31. Welp A, Meier LL, Manser T. Emotional exhaustion and workload predict clinician-rated and objective patient safety. Front Psychol. 2015;5:1-13.

32. Williams ES, Skinner AC. Outcomes of physician job satisfaction: a narrative review, implications and directions for future research. Health Care Manage Rev. 2003;28:119-40.

33. Spector PE. Job satisfaction: application, assessments, causes, and consequences. Thousand Oaks: SAGE publications, Inc; 1997.

34. Krueger P, Brazil K, Edward H, Lewis D, Tiam E. Organization specific predictors of job satisfaction: findings from a Canadian multi-site quality of work life cross-sectional survey. BMC Health Serv Res. 2002;2:6.

35. Ostroff $C$. The effects of climate and personal influences on individual behavior and attitudes in organizations. Organ Behav Hum Decis Process. 1993;56:56-90

36. Schmit Jongbloed LJ, Schönrock-Adema J, Borleffs JC, Stewart RE, CohenSchotanus J. The influence of achievement before, during and after medical school on physician job satisfaction. Adv Heal Sci Educ. 2014;19:581-95.

37. Schmit Jongbloed LJ, Schönrock-Adema J, Borleffs JCC, Steward RE, CohenSchotanus J. Physicians' job satisfaction in their begin, mid and end career stage. J Hosp Adm. 2017;6:1-8.

38. Carr JZ, Schmidt AM, Ford JK, DeShon RP. Climate perceptions matter: a meta-analytic path analysis relating molar climate, cognitive and affective states, and individual level work outcomes. J Appl Psychol. 2003;88:605-19.

39. Hojat M, Kowitt B, Doria C, Gonnella JS. Career satisfaction and professional accomplishments. Med Educ. 2010;44:69-76.

40. Moos RH. The social climate scales: an overview. Palo Alto: Consulting Psychologists Press; 1974.

41. McManus IC, Smithers E, Partridge P, Keeling A, Fleming PR. A levels and intelligence as predictors of medical careers in UK doctors: 20 year prospective study. Br Med J. 2003:327:139-42.

42. McMurray JE, Linzer M, Konrad TR, Douglas J, Shugerman R, Nelson K, et al. The work lives of women physicians results from the physician work life study. The SGIM Career Satisfaction Study Group. J Gen Intern Med. 2000;15:372-80.

43. SHM Career Satisfaction Task Force. A challenge for a new specialty: a white paper on hospitalist career satisfaction [Internet]. US; 2006. Available from: http://www.hospitalmedicine.org/whitepapers.

44. van Ham I, Verhoeven AAH, Groenier KH, Groothoff JW, De Haan J. Job satisfaction among general practitioners: a systematic literature review. Eur J Gen Pract. 2006;12:174-80. Available from: http://www.ncbi.nlm.nih.gov/ pubmed/17127604.

45. Wada K, Arimatsu M, Higashi T, Yoshikawa T, Oda S, Taniguchi H, et al. Physician job satisfaction and working conditions in Japan. J Occup Health. 2009;51:261-6.

46. IBM corp. IBM SPSS statistics for Windows. Armonk: IBM corp; 2011.

47. SAS Institute Inc. SAS for Windows. Cary: SAS Institute Inc.; 2009.

48. Kravitz RL. Physician job satisfaction as a public health issue. Isr J Health Policy Res. 2012;1. Available from: http://linkinghub.elsevier.com/retrieve/pii/ S0029784403006665

49. Cull WL, O'Connor KG, Olson LM. Part-time work among pediatricians expands. Pediatrics. 2010;125:152-7. Available from: http://pediatrics. aappublications.org/cgi/doi/10.1542/peds.2009-0767.

50. Harrison RA, Gregg JL. A time for change: an exploration of attitudes toward part-time work in academia among women internists and their division chiefs. Acad Med. 2009;84:80-6.

51. Levine RB, Harrison RA, Mechaber HF, Phillips C, Gallagher TH. Professional characteristics and job satisfaction among SGIM members: a comparison of part-time and full-time physician members. J Genera. 2008;23:1218-21.
52. Keeton $K$, Fenner DE, Johnson TRB, Hayward RA. Predictors of physician career satisfaction, work-life balance, and burnout. Obstet Gynecol. 2007:109:949-55. Available from: http://www.ncbi.nlm.nih.gov/pubmed/17400859.

53. Pas BR, Lagro-Janssen ALM, Doorewaard JACM, Eisinga RN, Peters CP. Genderverschillen in carrièremotivatie: Ambities van vrouwelijke artsen vooral gebaat bij carrièreondersteuning [Gender differences in career motivation: female doctors' ambitions benefit from family friendly work environment]. Ned Tijdschr Geneeskd. 2008;152:2172-6. Available from: https://www.ntvg.nl/artikelen/genderverschillen-carrièremotivatie-ambitiesvan-vrouwelijke-artsen-vooral-gebaat-bij.

54. Mechaber HF, Levine RB, Manwell LB, Mundt MP, Linzer M. Part-time physicians... prevalent, connected, and satisfied. J Gen Intern Med. 2008;23:300-3.

55. van Herwaarden CLA, Laan RFJM, Leunissen RRM. Raamplan Artsopleiding 2009. 2009. Utrecht, Available from: http://www.nfu.nl/img/pdf/Raamplan_ Artsopleiding_2009.pdf.

56. Capaciteitsorgaan. The 2013 recommendations for medical specialist training [Internet]. Utrecht; 2013. Available from: http://www.capaciteitsorgaan.nl/ publicaties/capaciteitsplan-2013-hoofdrapport-engelse-versie/

\section{Submit your next manuscript to BioMed Central and we will help you at every step:}

- We accept pre-submission inquiries

- Our selector tool helps you to find the most relevant journal

- We provide round the clock customer support

- Convenient online submission

- Thorough peer review

- Inclusion in PubMed and all major indexing services

- Maximum visibility for your research

Submit your manuscript at www.biomedcentral.com/submit
C Biomed Central 